\title{
Strategi Dakwah Lembaga Gerakan Ahli Sedekah dalam Penanaman Kesadaran Bersedekah di Bandung
}

\author{
Alifa Nur Ramdhani* \\ Prodi Komunikasi Penyiaran Islam, Fakultas Dakwah, Universitas Islam \\ Bandung, Indonesia. \\ *alifaramadhani99@gmail.com
}

\begin{abstract}
Islam as a da'wah religion requires each of its adherents to preach according to their abilities, da'wah can be carried out by anyone, both individuals or the scale of people, such as institutions, organizations, communities, one of which is the Alms Expert Movement Institute. This institution preaches by inviting people to give alms, because da'wah does not have to be through lectures or tausyiah but can be in the form of simple things such as alms. The theory used in this research is the concept of strategy proposed by Fred R. David in Strategic Management Concepts. The concept through which there are three stages in the strategy process. The three stages are the strategy formulation stage, strategy implementation, and strategy evaluation stage. The research method used in this study is a qualitative descriptive research method, namely analyzing data based on information obtained from interviews, documentation studies and direct observations at the Institute for the Alms Expert Movement. Based on the results of the research conducted by the author, the da'wah strategy that has been carried out by the Alms Expert Movement goes through strategic stages consisting of strategy formulation in the form of determining the vision, mission and goals, environmental analysis, and planning program activities. and implementation strategies in the form of programs that raise funds, programs that distribute funds, and educational programs. as well as an evaluation strategy that evaluates the program as a whole and a pre-program evaluation that is carried out.
\end{abstract}

Keywords: Strategy, Da'wah, Institution, Movement, Expert, Alms, Awareness.

Abstrak. Islam sebagai agama dakwah mewajibkan setiap pemeluknya untuk berdakwah sesuai dengan kemampuannya, dakwah dapat dilakukan oleh siapa saja baik perorangan atau skala orang banya seperti lembaga, organisasi, komunitas, salah satunya Lembaga Gerakan Ahli Sedekah. Lembaga ini berdakwah dengan mengajak masyarakat untuk bersedekah, karena dakwah tidak harus dengan ceramah atau tausyiah namun bisa berupa hal sederhana seperti sedekah. Teori yang digunakan dalam penelitian ini adalah konsep strategi yang dikemukakan oleh Fred R. David dalam Manajemen Strategis Konsep. Konsep yang dilalui terdapat tiga tahapan dalam proses strategi. Tiga tahapan tersebut adalah tahapan perumusan strategi, implementasi strategi, dan tahapan evaluasi strategi. Metode penelitian yang digunakan dalam penelitian ini adalah metode penelitian deskriptif kualitatif yaitu menganalisis data berdasarkan informasi- informasi yang diperoleh dari hasil wawancara, studi dokumentasi dan observasi langsung pada Lembaga Gerakan Ahli Sedekah. Berdasarkan hasil penelitian yang dilakukan penulis, strategi dakwah yang telah dilakukan oleh Gerakan Ahli Sedekah melalui tahapan-tahapan strategi yang terdiri dari strategi perumusan berupa menentukan visi, misi dan tujuan, analisis lingkungan, dan perencanaan program kegiatan. dan strategi implementasi berupa program yang menggalang dana, program yang menyalurkan dana, dan program edukasi. serta strategi evaluasi yang mengevaluasi program secara menyeluruh dan evaluasi yang bersifat preprogram yang dilaksanakan.

Kata Kunci: Strategi, Dakwah, Lembaga, Gerakan, Ahli, Sedekah, Kesadaran. 


\section{A. Pendahuluan}

Dakwah merupakan tugas seluruh umat muslim. Setiap umat muslim diwajibkan untuk berdakwah sesuai dengan kemampuan yang ia miliki. Secara umum, masyarakat hanya mengetahui bahwa dakwah dilakukan dengan cara bil-lisan, namun sebenarnya ada banyak cara yang dapat dilakukan untuk menyampaikan dakwah. Dakwah dapat juga dilakukan dengan bilhal (perbuatan), bil-qolam (tulisan). Dakwah dengan bil-hal (perbuatan) yaitu lebih kepada perbuatan,peran atau aksi kepada masyarakat seperti bakti sosial atau segala kegiatan yang dilakukan untuk masyarakat. Sedangkan dakwah dengan bil-qolam (tulisan) dapat dilakukan dengan menerbitkan sebuah artikel atau majalah, koran dan sebagainya tentang Islam.

Tujuan utama dari aktivitas dakwah ialah proses penyadaran, penyadaran yang dimaksud adalah menyadarkan manusia bahwa ada perintah dari Allah SWT untuk membantu kepada sesama utamanya seorang muslim terhadap muslim lainnya. Wujudnya dari bantuan tersebut dibingkai dalam sebuah hukum Islam yang disebut dengan zakat, infaq, shodaqoh, dan hibah. Dalam penelitian ini, peneliti akan lebih memfokuskan pembahasan pada proses dakwah yang berkaitan dengan aktivitas sedekah.

Sedekah merupakan salah satu strategi dakwah dengan bil-hal (perbuatan). Sedekah (shadaqoh) merupakan pemberian harta kepada orang- orang fakir, orang yang membutuhkan, atau pihak-pihak lain yang berhak menerima tanpa berharap imbalan atau keuntungan. Sedekah merupakan bagian dari dakwah yang mana sedekah menjadi salah satu amal ibadah yang harus dijalankan oleh masyarakat.

Sedekah (shadaqoh) diartikan dengan banyak penafsiran diantaranya, sedekah adalah pemberian harta kepada orang-orang fakir miskin, orang yang membutuhkan, ataupun pihakpihak lain yang berhak menerima, tanpa disertai imbalan atau keuntungan dari sedekah tersebut.

Karena dengan sedekah ini bisa membantu lebih banyak masyarakat, dan lebih luas sasarannya dibandingkan dengan zakat ataupun wakaf. Seperti yang kita ketahui, zakat itu penerima manfaatnya hanya terbatas oleh 8 asnaf, dan wakaf sesuai akad. Sementara sedekah ataupun infaq lebih luas dan fleksibel sehingga bisa dioptimalkan sesuai dengan kondisi saat itu yang dibutuhkan masyarakat tanpa harus merujuk kepada apa akad yang diberikan oleh pemberi.

Kurangnya kesadaran masyarakat dalam bersedekah ini sangat erat kaitannya dengan tingkat keimanan dan pengetahuan seseorang akan pentingnya sedekah itu sendiri. Diketahui bahwa banyak yang bersedekah menunggu kaya, menunggu ketika ada uang lebih. Namun setelah diberi kekayaan atau uang lebih, seringkali tidak disedekahkan atau dilupakan. Padahal sedekah tidak harus dengan harta, namun bisa dimulai dengan senyuman dan melakukan apapun yang kita bisa lakukan sesuai kemampuan diri.

Setiap individu yang beragama Islam, seharusnya memiliki kesadaran yang tinggi untuk bisa menafkahkan sebagian hartanya untuk yang membutuhkan. Setidaknya, apabila kesadaran ini muncul, bisa mengurangi tingkat kemiskinan yang sudah merajalela dimana-mana. Karena harta yang kita miliki sebenarnya terdapat hak untuk kaum fakir miskin atau orang yang membutuhkannya. Hal ini disebutkan dalan Al-Qur'an pada Q.S. Adz-Dzariyat ayat 19:

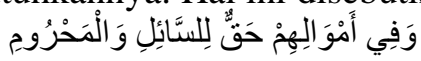

Artinya: Dan pada harta-harta mereka ada hak untuk orang miskin yang meminta dan orang miskin yang tidak mendapat bagian.

Berdasarkan ayat di atas inilah pesan penting yang hendaknya tidak dilupakan oleh umat Islam untuk bersedekah dengan tulus dan ikhlas, dengan niat beribadah dan berbagi dengan sesama yang membutuhkan, sesungguhnya harta yang disedekahkan itu tidak hilang, tetapi menjadi pinjaman Allah SWT dan akan diganti-Nya dengan lipat ganda. Namun, hal tersebut sangat sulit di realisasikan oleh masyarakat. Padahal sudah sangat jelas bahwa Allah SWT sudah memerintahkan kita agar selalu membantu sesama dengan bersedekah.

Gerakan Ahli Sedekah dengan strategi dakwahnya melakukan penanaman kesadaran bersedekah melalui manajemen dakwah dan psikologi dakwah masyarakat muslim di Indonesia baik secara langsung terjun ke lapangan dan juga melalui media sosial Instagram yang saat ini menjadi salah satu media dakwah yang lebih mudah diterima masyarakat. Bagi mereka, donator Gerakan Ahli Sedekah adalah setiap yang pernah berdonasi. 
Dengan demikian, pentingnya penyelesaian dari permasalahan tersebut yang ada di Lembaga Gerakan Ahli Sedekah ini akan berdampak diantaranya, pertama, meningkatnya penghimpunan akan meningkatkan kesejahteraan pengelola, karena meningkatnya kesejahteraan pengelola akan meningkatkan kinerja. Kedua, memberikan citra positif terhadap masyarakat lebih luas bahwa begitu banyak orang yang percaya terhadap lembaga ini. Karena berbicara mengenai sedekah yang dititipkan kepada lembaga sosial atau lembaga zakat bukan hanya sekedar bagaimana menarik dan memahamkan mereka, tetapi ada yang disebut dengan transparansi, akuntabilitas, dank has. Bicara sedekah bukan lagi bicara tentang pahala dan syurga, tetapi juga mengenai kepercayaan terhadap lembaga. Maka peningkatan jumlah donasi atas meningkatnya kesadaran bersdekah ini membawa dampak positif terhadap pencitraan lembaga di publik yang lebih luas.

\section{B. Metodologi Penelitian}

Metode yang digunakan adalah metode penelitian kualitatif yaitu dengan menggunakan penelitian yang menghasilkan data deskriftif berupa kata-kata tertulis dari orang atau perilaku yang diamati, kegiatan penelitian ini merupakan data yang diambil dari lapangan penelitian dengan pendekatan survey, data yang dikumpulkan berupa fakta-fakta, gambar dan bukan angka-angka. Dalam hal ini penulis melakukannya dengan mengamati dan mengumpulkan datadata dan kemudian data-data yang diperoleh disusun dan dikembangkan dan selanjutnya dikemukakan dengan seobjektif mungkin kemudian dianalisa. Teknik pengumpulan data yang di lakukan dari penelitian ini adalah, wawancara, foto kegiatan dan area masjid juga disertai bukti deskriptif fakta yang terjadi di lapangan.

\section{Pembahasan dan Diskusi}

Gerakan Ahli Sedekah pada kegiatan dakwahnya berfokus pada penanaman kesadaran bersedekah kepada para masyarakat, donatur dan calon donatur, materi yang disampaikan diantaranya kesadaran ber-ZISWAF, materi tentang keharusan berinfaq dan shadaqoh, hal ini dilakukan untuk menunjang program kegiatan Gerakan Ahli Sedekah untuk disebarluaskan pada masyarakat luas. Di Gerakan Ahli Sedekah dalam membuat tingkat kesadaran bersedekah di bandung khususnya selalu membuat pengelolaan soal transparasi dana yang disalurkan, hal ini membuat donatur dan calon donatur tertarik untuk senantiasa menitipkan harta nya untuk dialurkan pada yang berhak menerimanya melalui proses yang disepakati oleh pengurus, walaupun tingkat kesadarann bersedekah dari para donatur dan calon donatur tidak selama nya stabil. Peneliti melihat Gerakan Ahli Sedekah dalam membuat sebuah strategi dakwah sudah cukup baik, ini berdasarkan adanya sebuah Perumusan, Implementasi, dan Evaluasi, dimana Gerakan Ahli Sedekah melakukan sebuah perumusan program untuk disebarluaskan pada target mad'u nya, juga menyusun sebuah SDM implementasi untuk mengelola dan memberikan materi pada mad'u, dan evaluasi untuk senantiasa melihat apa saja yang berjalan dengan baik dan meminimalisir setiap kesalahan dari mulai komunikasi, dan koordinasi.

\section{Kesimpulan}

1. Gerakan Ahli Sedekah pada kegiatan dakwahnya berfokus pada penanaman kesadaran bersedekah kepada para masyarakat, donatur dan calon donatur, materi yang disampaikan diantaranya kesadaran ber-ZISWAF, materi tentang keharusan berinfaq dan shadaqoh, hal ini dilakukan untuk menunjang program kegiatan Gerakan Ahli Sedekah untuk disebarluaskan pada masyarakat luas.

2. Gerakan Ahli Sedekah dalam membuat tingkat kesadaran bersedekah di bandung khususnya selalu membuat pengelolaan soal transparasi dana yang disalurkan, hal ini membuat donatur dan calon donatur tertarik untuk senantiasa menitipkan harta nya untuk dialurkan pada yang berhak menerimanya melalui proses yang disepakati oleh pengurus, walaupun tingkat kesadarann bersedekah dari para donatur dan calon donatur tidak selama nya stabil. 
3. Gerakan Ahli Sedekah dalam membuat sebuah strategi dakwah sudah cukup baik, ini berdasarkan adanya sebuah Perumusan, Implementasi, dan Evaluasi, dimana Gerakan Ahli Sedekah melakukan sebuah perumusan program untuk disebarluaskan pada target mad'u nya, juga menyusun sebuah SDM implementasi untuk mengelola dan memberikan materi pada mad'u, dan evaluasi untuk senantiasa melihat apa saja yang berjalan dengan baik dan meminimalisir setiap kesalahan dari mulai komunikasi, dan koordinasi.

\section{Acknowledge}

Penulis mengucapkan terimakasih, atas waktu dan kesempatan yang diberikan terhdap penelitian yang dilakukan, semoga menjadi manfaat dan hal positif untuk memajukan sebuah masjid yang diimpikan seperti halnya Rasulullah Saw.

\section{Daftar Pustaka}

[1] Anas, Ahmad. Paradigma Dakwah Kontemporer, Semarang: Walisongo, 2005.

[2] Arifin, Anwar. Dakwah Kontemporer, Bandung: Remaja Rosda Karya, 2010.

[3] Aripudin, Acep. Pengembangan Metode Dakwah, Jakarta: Raja Grafindo Persada, 2011. Cet ke 1.

[4] Ash Shiddieqy, M. Hasbi. Pedoman Zakat, Semarang: Pustaka Rizki Putra, 2006. cet ke-11.

[5] Bachtiar, Wardi. Metodologi Penelitian Ilmu Dakwah, Jakarta: Logos, 1997.

[6] Badruttaman, Nurul. Dakwah Kolaboratif Tarmizi Taher, Jakarta: Penerbit Grafindo Khazanah Ilmu, 2005, cet ke-1.

[7] Cangara, Hafied. Perencanaan Dan Strategi Komunikasi, Jakarta: Rajawali Pers, 2013, cet. ke-1.

[8] David, Fred.R. Strategic Management Concepts and Cases Thirteenth Edition NewJersey: Pearson Education Inc, 2007.

[9] Departemen Pendidikan Nasional. Kamus Besar Bahasa Indonesia,

[10] Jakarta: Balai Pustaka, 2002.

[11] Ghazali, M. Bahri. Da'wah Komunikatif, Jakarta: Pedoman Ilmu Jaya, 1997, cet ke-1.

[12] Hafidhuddin, Didin. Dakwah Aktual, Jakarta: Gema Insani Press, 1998, cet ke-1. ke-2.

[13] Haroen, Nasrun. Fiqh Muamalah, Jakarta: Gaya Media Pratama, 2007, cet Herdiansyah, Haris. Metode Penelitian Kualitatif, (Jakarta: Salemba Humanika, 2010.

[14] Hubeis, Musa dan Mukhamad Najib. Manajemen Strategik, Jakarta: Elex Media Komputindo, 2014, cet ke-1. 